\title{
Newborn transient patterned hyperpigmentation and anophthalmia
}

\author{
Oscar F. Chacón-Camacho ${ }^{1,2 *}$, Rocío Arce-González¹, and Genaro Rodríguez-Uribe ${ }^{3}$ \\ ${ }^{1}$ Departamento de Genética, Instituto de Oftalmología Conde de Valenciana, Mexico City; ${ }^{2}$ Departamento de Genética y Biología Molecular, Facultad \\ de Estudios Superiores Iztacala, Universidad Nacional Autónoma de México, Tlalnepantla, State of Mexico; ${ }^{3}$ Facultad de Medicina y Psicología, \\ Universidad Autónoma de Baja California-Campus Tijuana, Tijuana, Baja California. Mexico
}

\begin{abstract}
Background: Transient pigmentary lines of the newborn are uncommon cutaneous lesions of unknown etiology. To date, only a few cases have been described. Case report: A patient with a combination of transient pigmentary lines and ocular malformation is described. Molecular analysis of the SRY-box 2 (SOX2) and MIFT genes was conducted to rule out any monogenetic etiology. Conclusions: Worldwide, this is the eighth case of transient pigmentary lines of the newborn reported, and the first associated with anophthalmia. No mutations in the analyzed genes (SOX2 and MIFT) were identified. Therefore, somatic mutations could be responsible for this anomaly.
\end{abstract}

Key words: Transient pigmentary lines. Lineal skin hyperpigmentation. Anophthalmia. SRY-box 2. MIFT.

\section{Patrón de hiperpigmentación transitoria del recién nacido y anoftalmia}

\section{Resumen}

Introducción: Las líneas transitorias pigmentarias del recién nacido son lesiones cutáneas poco comunes. A la fecha, pocos casos se han descrito. Caso clínico: Paciente neonato con la combinación de líneas transitorias hiperpigmentadas y una malformación ocular. Se realizó secuenciación molecular de los genes SOX2 y MIFT para descartar una etiología monogénica. Conclusiones: En todo el mundo, este es el octavo caso reportado de líneas transitorias hiperpigmentadas del recién nacido, y el primero asociado con anoftalmia. No se identificaron mutaciones en los genes estudiados (SOX2 y MIFT). Por lo tanto, las mutaciones somáticas pueden ser la causa de la afección.

Palabras clave: Líneas transitorias hiperpigmentadas. Piel lineal hiperpigmentada. Anoftalmia. SOX2. MIFT.

\section{Introduction}

Pigmentary or vascular abnormalities can cause transient skin color changes in the newborn. Pigmentary anomalies can be related to melanin pigment with dermal melanosis (Mongolian spots) and transient epidermal hyperpigmentation, being typical examples of melanin-related abnormal pigmentation 1 . In the newborn, transient hyperpigmentation can be found in genital areas, lower abdomen, areolae, axillae, pinnae, and in the base of the fingernails, most probably due to in utero hormonal influence (melanocyte-stimulating hormone [MSH]). However, non-hormonal hyperpigmentation patterns can also occur, such as the horizontal
Correspondencia:

*Oscar Francisco Chacón Camacho

E-mail: oscar_chacon73@hotmail.com DOI: 10.24875/BMHIM.20000191
Disponible en internet: 23-04-2020 Bol Med Hosp Infant Mex. 2020;77(3):146-148

www.bmhim.com 1665-1146/C 2020 Hospital Infantil de México Federico Gómez. Published by Permanyer. This is an open access article under the license CC BY-NC-ND (http://creativecommons.org/licenses/by-nc-nd/4.0/). 
bands of hyperpigmentation in the abdomen or back, which are temporary and of unknown etiology ${ }^{1}$. To date, only a few reports have described this anomaly known as transient pigmentary lines of the newborn ${ }^{2-8}$.

Microphthalmia/anophthalmia/coloboma (MAC) constitutes the spectrum that results in uni or bilateral malformations of the eye due to failure of the primary optic vesicle, reduction of the axial length of the ocular globe, or failure of the closure of the optic fissure, respectively. MAC has a prevalence of 2 in 10,000 in the population and may be sporadic or familial, isolated, or part of a syndromic disease ${ }^{9}$. In this report, a male newborn, exhibiting the unusual combination of transient infantile patterned hyperpigmentation and ocular malformations, is described. To the best of our knowledge, this entity has not been previously described in the literature. The sequencing of SRY-box 2 (SOX2) and Melanocyte-inducing transcription factor (MITF) genes was conducted to investigate a possible monogenic origin of anophthalmia. The first gene was analyzed because it is the most common etiology of monogenetic anophthalmia. In contrast, the other gene was studied because it is implicated in ocular malformations, such as anophthalmia, and congenital anomalies of pigmentation.

\section{Case report}

A 1-month-old male was referred to the Genetics Department due to linear dermatologic hyperpigmentary abnormalities and ocular malformations. He was the only child of young, non-consanguineous, healthy parents. His family history was uneventful, and his mother reported no exposure to potential teratogenic agents. He was born by abdominal delivery, with a weight of $3800 \mathrm{~g}$ (percentile 50) and $52 \mathrm{~cm}$ (percentile 75) of height. Other somatometric newborn measures were unknown. On examination, multiple dark, horizontal, and pigmentary lines were observed, initiating in the thorax under the nipples and extending to the pelvic region. Seven distinct dark horizontal pigmentary lines were observed, which were divided by perpendicular dark lines located from the thorax to the pelvis (Figure 1A). Additional dark parallel linear pigmentary lesions were detected in the thoracic and pelvic limbs (Figure 1B). Right anophthalmia was found and confirmed by ocular echography. The left eye was normal. Unfortunately, subsequent clinical assessments were not possible. After obtaining the parental informed consent, a blood sample was drawn from the patient. The polymerase chain reaction amplification was

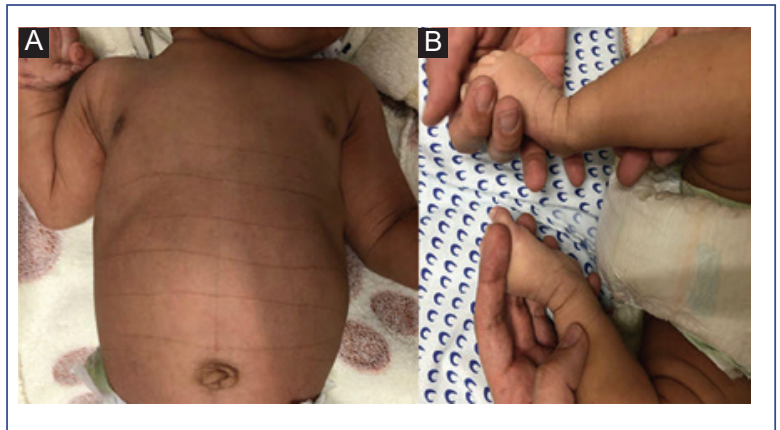

Figure 1. Linear pigmentation of the abdomen $\mathbf{A}$ : and pelvic limbs B: following skin folds.

performed, followed by the Sanger sequencing of the complete coding sequences of SOX2 and MIFT genes. No mutations were identified. A biopsy of the pigmentary lesion was not allowed by the parents.

\section{Discussion}

At present, the etiology of transient patterned hyperpigmentation is unknown. It has been hypothesized that it may be caused by the stimulation of the MSH in utero, a mechanical trauma from hyperkeratosis due to a fetal posture of flexion in utero that leads to post-inflammatory hyperpigmentation, or due to abnormalities of skin exfoliation as a consequence of fetal flexion ${ }^{4,5,7}$.

Only eight patients with transient lines of hyperpigmentation have been reported, including the present case. This uncommon disease was first characterized in 1967, with lines persisting for 4 months $^{2}$. Although most cases are isolated, other associated anomalies have been reported, such as ichthyosis vulgaris, ventral hernia ${ }^{2}$, and multiple macular hyperpigmentation on the back and over the spinal column ${ }^{4}$.

In this patient, unilateral anophthalmia was also observed, which raised the possibility of a common origin for both skin and ocular anomalies, although both abnormalities may also be isolated entities. To rule out a Mendelian origin of both congenital defects, a molecular analysis of SOX2 was performed, because this gene is the common cause of the Mendelian MAC spectrum $^{9}$. SOX2 may induce the proliferation of epithelial and connective tissue cells ${ }^{10}$. Furthermore, our group reported the association of anophthalmia with dental abnormalities originated from epidermal tissue. Furthermore, the MIFT gene was analyzed since it encodes a central protein for the development of neural 
crest-derived melanocytes and optic cup-derived tissues $^{10}$. MITF mutations are a well-established cause of the Waardenburg syndrome type $2 \mathrm{~A}$, a disease exhibiting both ocular and melanogenesis defects. However, no mutations in either SOX2 or MITF genes were identified.

To the best of our knowledge, this patient is the eighth case reported in the literature with transient patterned hyperpigmentation, and the first one associated with anophthalmia. A monogenetic cause for this uncommon association could not be demonstrated after the molecular analysis of SOX2 and MITF genes. Both entities may be isolated; however, a genetic origin or even a low proportion of somatic mosaicism cannot be ruled out as the etiology of the disorder.

\section{Ethical disclosures}

Protection of human and animal subjects. The authors declare that the procedures followed were in accordance with the regulations of the relevant clinical research ethics committee and with those of the Code of Ethics of the World Medical Association (Declaration of Helsinki).

Confidentiality of data. The authors declare that they have followed the protocols of their work center on the publication of patient data.

Right to privacy and informed consent. The authors have obtained the written informed consent of the patients or subjects mentioned in the article. The corresponding author is in possession of this document.

\section{Conflicts of interest}

The authors declare that they have no conflicts of interest.

\section{Funding}

None.

\section{References}

1. Lucky AW. Transient benign cutaneous lesions in the newborn. In: Eichenfield LF, Frieden IJ, editors. Textbook of Neonatal Dermatology. Philadelphia, PA: WB Saunders Company; 2001. p. 97-9.

2. Gibbs RC. Unusual striped hyperpigmentation of the torso. A sequel of abnormalities of epitrichial exfoliation. Arch Dermatol. 1967;95:385-6.

3. Halper S, Rubenstein D, Prose N, Levy ML. Pigmentary lines of the newborn. J Am Acad Dermatol. 1993;28:893-4.

4. Martín JM, Jordá E, Alonso V. Transient pigmentary lines of the newborn. Pediatr Dermatol. 2009;26:768.

5. Monteagudo B, León-Muiños E, Suárez-Amor O, Labandeira J. Transient pigmentary lines of the newborn. Actas Dermosifiliogr. 2013;104:537-9.

6. Garg G, Bhalla M, Thami GP. Transient infantile patterned hyperpigmentation. Pediatr Dermatol 2012;29:372-3.

7. Fosse N, Itin P. Pigmentary lines of the newborn: A case report and review of the literature. Dermatology. 2014;228:198-201.

8. Terry M, Marlowe Stewart D. Transient pigmentary lines of the newborn in a postmortem examination: A case report. Am J Forensic Med Pathol. 2019:40:171-4.

9. Bardakjian T, Weiss A, Schneider A. Microphthalmia/anophthalmia/coloboma spectrum. In: Adam MP, Ardinger HH, Pagon RA, editors. Gene Reviews $^{\circledR}$. Seattle, WA: University of Washington, Seattle; 1993-2019.

10. Uchiyama A, Nayak S, Graf R, Cross M, Hasneen K, Gutkind JS, et al SOX2 Epidermal overexpression promotes cutaneous wound healing via activation of EGFR/MEK/ERK signaling mediated by EGFR ligands. $J$ Invest Dermatol. 2019;139:1809-20. 